\title{
An Inflation Targeting Regime in Egypt: A Feasible Option?
}

\author{
Tarek Ghalwash \\ Department of Economics, Mansoura University, Mansoura, Egypt \\ E-mail: tarek.ghalwash@econ.umu.se \\ Received June 6, 2010; revised July 10, 2010; accepted July 15, 2010
}

\begin{abstract}
This paper addresses first whether scientific evidence - theoretical and empirical-exists to support the inflation targeting regime and, secondly whether inflation target is worthwhile for Egypt. The method in this paper builds on a literature review of the theoretical and empirical research in the field of economics. Our conclusion shows that there is incomplete evidence from a number of countries supporting the inflation targeting regime as an effective monetary policy framework for the achievement of macroeconomic stability. The paper concludes that the Central Bank of Egypt and the Egyptian economy is not yet ready for the implementation of an inflation targeting regime.
\end{abstract}

Keywords: Inflation Targeting, Monetary Regimes, Granger Causality Test

\section{Introduction}

The fact that the inflation problem has received increasing attention in recent years has led to an increased interest in the effects of different monetary policy regimes. By "effects" we partly mean what governments want to achieve (i.e., a price stability, output growth), but also the effects on the economy performance so that it can succeed in an increasingly competitive world market. In other words, the interest in price stability policy issues is not only related to the "benefit side" but also the "cost side." It is well known that the main focus of monetary policy should be attaining low, stable inflation, since any deviating from this objective may have serious consequences in terms of growth stability and economic welfare [1].

There seems to be a wide consensus among economists that high and volatile inflationary rates distort relative prices, discourage savings and investment, hinder economic growth and development, and can induce social and political instability. In the quest to avoid this malaise, there are traditionally three aggregates that serve as an anchor for monetary policy management: a monetary aggregate, exchange rate, and inflation itself, which is called inflation targeting.

${ }^{1}$ Inflation targeting is a monetary regime that was first introduced in New Zealand in 1990 and as of 2006 had been adopted by more than twenty advanced and emerging economies (See Roger and Stone [2]).
Recently, Inflation target has become the dominant monetary policy prescription for a number of developing and industrialized countries and has been widely talked about as an economic policy ${ }^{1}$. Many countries have adopted inflation targeting as a monetary policy with the hopes of effectively reducing inflation and increasing economic and price stability. Even though it is often claimed that inflation targeting has helped these countries achieve lower and more stable inflation along with more stable output, there is no conclusive evidence that inflation targeting directly caused the improved economic performance [3].

The adoption of an inflation targeting monetary framework that started in New Zealand in 1990, is currently popular among a number of emerging market countries such as Brazil, Chile, Colombia, The Czech Republic, Hungary, Israel, Korea, Mexico, Poland, South Africa, Thailand and Turkey. In the West African sub-region, Ghana has also adopted inflation-targeting monetary framework and other African countries are at various preparatory stages of adopting it.

The debate over the effectiveness of inflation targeting to reduce price levels has been overshadowed in recent year by the financial crisis originating in the sub prime mortgage market and the run up in energy and food prices. It has focused on the view that inflation targeting places too much emphasis on inflation, potentially at the expense of other monetary policy goals. Some critics of inflation targeting see recent macroeconomic develop- 
ments as being the downfall of inflation targeting ${ }^{2}$.

Economists have started debating the pros and cons for developed and developing countries to shift from the current regime to inflation targeting. In light of these debates, one can view the debate in, for example, Egypt with regard to the country's desire to be at the forefront of switching to an inflation targeting regime especially in the Middle East area ${ }^{3}$. On that front, the Central Bank of Egypt (CBE) announced in June 2005, its intention to "put in place a formal inflation targeting framework to anchor monetary policy once the fundamental prerequisites are met".

To our knowledge, there are few earlier studies dealing with whether Egypt is ready for inflation targeting, ${ }^{4}$ as there are a number of requirements to be met for such regime to be a sensible option as a monetary regime. Investigation is also needed as to whether the Egyptian Centre Bank (ECB) has considered the full implications of shifting to inflation targeting, in particular as to how this monetary regime will contribute to other objectives of the country, such as growth, employment creation and poverty reduction. Therefore, the main contribution of the present paper is to fill this gap in the debate.

This paper will not assess the pros and cones of inflation targeting as this has been extensively discussed in previous studies: See, for example, [6-9]. It has, however, been observed by [10] that the growing number of countries that target inflation and the perceived success of this monetary policy strategy serve as a stimulus for countries that engage in alternative regimes - such as monetary or exchange rate targeting. This consideration raises the question of how to evaluate whether a country is ready to join the group of inflation targeters now, later or even never.

This paper aims to give a systematic review of the inflation targeting regime. The fundamental question is whether scientific evidence - theoretical and empiricalexists to support the inflation targeting regime. If inflation targeting can be supported, does it only apply within specific preconditions? Furthermore, a closer look at the case of Egypt is presented by reviewing recent evidence to asses whether it is ready to switch to inflation targeting. Thus, the main objective in this paper entails not only a full understanding of the theoretical basis underlying inflation targeting but also attempts to answer the question, is inflation targeting worthwhile in general, and especially for Egypt?

The method along of this paper builds on a literature review of the theoretical and empirical research in the

\footnotetext{
${ }^{2}$ Joe Stiglitz, for example, has written that "Today, inflation targeting is being put to the test - and it will almost certainly fail".

${ }^{3}$ Israel and Turkey are already adopting inflation targeting as a monetary policy framework.

${ }^{4}$ [4] and [5] examined whether Egypt is ready to adopt inflation target or not without examining whether this policy would be good for Egyptian economy as a whole.
}

field of economics. The rest of the paper is structured as follows: Section 2 provides a systematic assessment of what is meant by the inflation targeting policy and what are the important preconditions for applying it. One of the objectives of this section is to provide an overview of the current understanding in the literature with respect to the applicability and relevance of the inflation target regime. Section 3 discusses the empirical evidence on the effects of inflation targeting in developed and developing countries and some of the lessons for monetary policy that can be drawn from the experiences of inflation targeting of Central Banks. Section 4 discusses whether Egypt satisfies the preconditions for adopting inflation targeting. Section 5 concludes with a summary of current knowledge and to what extent this information can provide guidance to Egyptian policy-makers.

\section{Monetary Policy Instruments, what does Inflation Targeting Mean?}

\subsection{Definition of Inflation Targeting}

Economists and monetary policy makers have long believed that successful monetary policy should have a "nominal anchor", a variable that the central bank could use to discipline their policy decisions and convince agents in the economy that the central bank was disciplined [11]. Various nominal anchors have been used in countries: examples are monetary aggregates and the exchange rate. In recent times, many countries in the world have moved towards a system/framework for conducting monetary policy known in academic and policy circles as "Inflation Targeting". As the name indicates, the nominal anchor is the inflation rate: the central bank is supposed to follow a monetary policy that is designed to achieve a stated objective with regard to the inflation rate.

A review of the literature reveals several interpretations of the definition of the inflation target. Inflation targeting is often defined as a framework for monetary policy, characterized by the public announcement of official quantitative targets (or target ranges) for the inflation rate, over one or more time horizons, and by explicit acknowledgment that low, stable inflation is the monetary policy's primary long run goal ( see $[12,13]$ and [14]). According to [15], inflation targeting is not a method to reduce the current inflation but an anchor to monitor and control price stability in an economy after a thorough disinflation period.

With regards to literature discussions, [16] argues that the inflation targeting regime encompasses five main elements:1) the announcement to the public of an explicit quantitative target or range for a period of time; 2) an institutional commitment to price stability as the primary goal of monetary policy, to which other goals are subordinated, meaning that a country is more likely to adopt 
inflation target in the absence of fiscal and financial dominance; 3 ) the central bank should have powerful models to make inflation forecasts, which use some indicators and variables containing information on future inflation; 4) increased transparency of the monetary policy strategy through communication with the public and the markets about plans, objectives, and decisions of the monetary authorities; and 5) increased accountability of the central bank for attaining its inflation objectives. These defining features of inflation targeting require that the country's monetary authorities have the technical and institutional capacity for modeling and forecasting domestic inflation and have some idea or prediction of the time it takes for the determinants of inflation to have their full effect on the inflation rate. The inflation target provides full transparency in the implementation of monetary policy that enables financial institutions in the market to foresee the future with less uncertainty and behave accordingly.

The conclusion that can perhaps be drawn from the previous discussion about the inflation targeting is that: the inflation targeting entails much more than a public announcement of numerical targets for inflation for the year ahead. This is important in the context of emerging and developing markets because many of them routinely reported numerical inflation targets or objectives as part of the government's economic plan for the coming year, and yet their monetary-policy strategy should not be characterized as inflation targeting, as it requires all the elements mentioned above for it to be sustainable over the medium term. The main issue raised right now is how an inflation target model as a monetary policy regime works?

\subsection{Inflation Target Model}

The simple version of this model can be written as follows (see [17]):

$$
\begin{aligned}
& \pi_{i t}=\pi_{t}^{*}+\alpha_{2} \mathrm{E}_{t}\left(\pi_{t+1}-\pi_{t+1}^{*}\right)+\alpha_{3}\left(H_{t}-H_{t}^{*}\right)+\varepsilon_{t} \\
& H_{t}=E_{t}\left(H_{t+1}\right)-\sigma\left(r_{t}-r_{t}^{*}-E_{t} \pi_{t+1}+\varepsilon_{t}\right) \\
& r_{t}=r_{t}^{*}+\lambda_{1}\left(\pi_{t}-\pi_{t}^{*}\right)+\lambda_{2}\left(H_{t}-H_{t}^{*}\right)
\end{aligned}
$$

where $\pi$ is inflation rate, $\pi^{*}$ is the central bank's inflation target, $E_{t}$ is Expectation on time $t,\left(H_{t}-H_{t}^{*}\right)$

\footnotetext{
${ }^{5}$ The literature interprets $r^{*}$ as the rate that is consistent with 'neutral' monetary policy. This means that if the real funds rate is equal to the natural rate, then monetary policy will be consistent with both the inflation and output and output targets.

${ }^{6}$ The forward-looking specification is an attempt to overcome the parameter instability commonly found after structural breaks. It is also motivated by the natural assumption that, as the inflation targeting regime gains credibility, expectations tend to converge to the targeted value.

${ }^{7}$ Because the changes on the interest rates policy will bring $\pi$ closer to $\pi^{*}$.
}

is output gap and $r$ is interest rate and the symbol* refers to target or long-run variables (or 'natural' in the case of interest rate; $H^{*}$ is the full-employment NAIRU level of output $)^{5}$. The last term, $\varepsilon_{t}$ is an error term reflecting unobserved shock (random shock). The model contains three equations and three unknowns, namely, output, inflation and the interest rate. Firms are assumed to index their prices to their assessment of the central bank's inflation target, and $\pi_{t}^{*}$ is the public's current estimate of the central bank's target.

Equation (1) is a price equation or a simple forwardlooking Phillips curve ${ }^{6}$. The output gap explains the inflation gap. In this model, inflation is caused by the output gap and the latter is caused by interest rate policies (see Equation (2)). Equation (2) is the expectation IS curve. Interest rate deviations from the target explain the output gap. If the central bank sets the interest rate below the natural rate, firms will find it profitable to borrow from the banking system to finance their Investment plans. Thus output will grow and the output gap will decrease. Equation (3) is Taylor's rule. It does not contain a random error because it is assumed that monetary policy operates without random errors. It is also assumed that $\lambda_{1} \succ 0$ for stability of the equilibrium. If actual output gets close to the potential or if inflation rises above target, the central bank will increase nominal interest rates (and indirectly real interest rates).

To see how the model works, consider the central bank announcement to the public regarding the formal target inflation rate. This can align the public's expectations of current and future target rates with the actual goals of the central bank. For example, reducing the public's assessment of the current and future target inflation rates would allow average inflation to fall without any associated cost in terms of real economic activity. This implies that the monetary authorities can set any inflation target they desire without having any effect on the real equilibrium of the economy, i.e., the equilibrium level of real output is unaffected by a shock; only the equilibrium level of inflation changes ${ }^{7}$. This also implies that, given the independence of the real economy from the inflation target, inflation targeting becomes an autonomous policy objective. Therefore, the stability of the system is guaranteed by the countercyclical role of the central bank in setting interest rates.

In the same manner, the inflation target regime can also allow the central bank to reduce both inflation and output volatility by anchoring the public's beliefs about future inflation. If a positive inflation shock causes the public to, (incorrectly), adjust upwards their estimate of the central bank's target, a larger decline in the output gap is necessary in order to limit the rise in actual inflation through rising of interest rates. Greater stability of inflation expectations should reduce the volatility of inflation and improve the short-run inflation-real activity 
trade off faced by the central bank. This, in turn, means that the volatility of both inflation and real activity would be lower under inflation targeting. In addition, when monetary policy is based on an inflation target regime, the central bank inflation forecast plays a key role in this regime. Therefore, the corresponding interest rate path is necessary for the private sector to determine the central bank's forecast of potential output because providing interest rate projection is very important for reducing uncertainty. According to the theoretical model, a feasible, and optimal, policy would set both inflation and the output gap equal to zero for all $t$. In this case, an interest policy consistent with such equilibrium would ensure that $r_{t}=r_{t}^{*}$ for all $t$. Given zero inflation, it is clear that the output gap only depends on the current and expected future interest rate gaps. This means that the inflation target can reduce the public's uncertainty about either the current target or future targets. This can be easily seen by rewriting the Phillips curve as

$$
\begin{aligned}
\pi_{i t}= & \alpha_{1} \pi_{t}^{T}+\alpha_{2} E_{t}\left(\pi_{t+1}-\pi_{t+1}^{T}\right) \\
& +\alpha_{3}\left(H_{t}-H_{t}^{*}\right)+\mu_{t}
\end{aligned}
$$

Where:

$$
\mu_{t}=\varepsilon_{t}-\left(\pi_{t}^{T}-\pi_{t / t}^{T}\right)
$$

The new random error term in the Equation (4), is now composed of the original random shock and errors in the public's forecast of the central bank's inflation target. Thus, reductions in forecast errors associated with the public's assessment of the inflation target, like a reduction in the variance of the cost shock, allow both inflation (around target) and the output gap to become more stable. In this case, the interest rate projection would only provide the public with the central bank's assessment of future demand shocks to which the policy rate will presumably be adjusted to offset.

Following the pervious analysis, it seems that the main argument in favor of inflation targeting is that an official announcement of an inflation target makes a central bank's policy more credible, which helps to alleviate the dynamic inconsistency problem, and thus should lead to lower (expectations of) inflation and inflation variability ${ }^{8}$. Further, one can draw the conclusion that the transparency on how monetary policy operates under inflation targeting makes the formation of inflation expectations easier, thereby strengthening the ability of central banks to achieve inflation targets, and therefore, prompting other central banks to mimic this practice.

\footnotetext{
${ }^{8}$ If credible, inflationary expectations are more accurate allowing businesses and consumers to better plan their production and spending.

${ }^{9}$ This means that the central bank should not be required to attain low interest rates on public debt or to maintain a particular nominal exchange rate.

${ }^{10}$ Usually, accountability is not established by explicit legislation, but through the transparency of monetary policy that inflation targeting creates.
}

\subsection{Preconditions for Inflation Targeting Regime}

The literature and experience of long-time inflation targeters have identified preconditions which have to be fulfilled in order to implement successful inflation targeting [18]. The first and probably the most important precondition for implementing the inflation targeting is that the central bank must be given complete independence to adjust freely its instruments of monetary policy toward the attainment of the objective of low inflation. Central bank needs to have the freedom to set its instruments of monetary policy in a way it believes that the objective will be achieved most adequately. Instrument independence mainly implies that the central bank is not constrained by the need to finance the government budget $^{9}$. In addition, there should not be any political pressure on the central bank to raise the rate of economic growth in such a way that is inconsistent with the achievement of the inflation target [19].

The second precondition for implementation of inflation targeting is the existence of efficient monetary policy instruments. According to this condition, monetary authorities have to be able to model inflation dynamics in the country and to forecast the inflation to a reasonable degree [20]. So, the monetary authorities should have access to policy instruments that are effective in influencing the macroeconomic variables. And also, there must be sufficiently developed money and capital markets to react quickly to the use of those instruments because the monetary policy's tools to achieve an inflation target may weaken the positions of the banks and may lead to the undershooting of the inflation target.

The third, but not less important precondition for inflation targeting is closely connected to the credibility. Under the inflation target regime, the country should incorporate transparency and accountability into the central bank's function. Both, accountability and transparency are dominantly determined by the quality of central banks communication to the public. It is very important for the central bank to inform the public about every circumstance connected to its policy, in order to make its goals and instruments clear and controllable. The public can use this information to form better expectations about future policy actions and keep track of the central bank's performance. In addition, the increased accountability of inflation targeting enables the monetary authority to monitor and enhance the understanding of expectations. It also decreases the possibility of a time inconsistency trap, which leads to deviations from monetary authority's long-term objective. Moreover, it provides a good benchmark that can easily be observed by the agents in the economy $[21]^{10}$. A transparent monetary policy makes it more difficult for a central bank to deviate from set targets, since such behaviour would have serious and long-lasting impact effects on its credibility. 
Central bank transparency should involve making inflation target explicit and public. This means that the central bank should have some form of published communication which not only announces the target but also describes the policy actions needed to reach and maintain the inflation target.

To conclude, the previous discussion has highlighted the importance of preconditions for successful inflation targeting.

\section{Inflation Targeting in Emerging Countries: Empirical Evidence}

The objective in this section is to review the empirical literature for developed and developing countries that is relevant to the objectives of this paper. An attempt will be made to present a systematic review, considering different aspects of inflation targeting regime, such as regulatory effects on 1) inflation rate, 2) real economy, and 3) expected inflation.

\subsection{Evidence in Developed Countries}

As mentioned above the academic debate around the inflation target regime started soon after New Zealand first instituted this monetary policy framework in early 1990. Since that time, 22 countries have formally adopted inflation targeting, and no country that has adopted it has abandoned it, although inflation targeting contribution to overall economic performance is still being debated.

There is an extensive empirical literature related to the connection between inflation targeting regime as a monetary policy and economic performance. The finding of empirical studies shows that inflation targeting countries have succeeded to reduce inflation and the volatility of inflation and to obtain inflation outcomes closer to target levels [22].

Reference [6] compares average inflation levels for seven inflation targeting countries with 7 countries excluding nontargeters countries. This contribution finds a much steeper decline in inflation in the case of the former group, concluding that inflation targeting is useful for countries facing lack of anti-inflation credibility. [23] interpret similar results as a process of 'convergence', in that on average inflation targeting countries converge to the inflation rates of the non- inflation targeting countries in the targeting period. [24] are able to conclude that inflation targeting countries have been able to meet their inflation targets and reduce inflation volatility ${ }^{11}$.

\footnotetext{
${ }^{11}$ Comparing the pre-targeting period with the post-targeting period may not capture the impact of inflation targeting per se, but rather a re-orientation of monetary policy towards lowering inflation (which could be achieved with or without inflation targeting). Comparisons between inflation-targeting countries and non-targeting countries are weaker and, again, depend on the control group used.
}

Closely related to the previous results, [25] employ cross-section difference-in-difference regressions to examine the treatment effects of inflation targeting in 20 OECD countries, seven of which adopt inflation targeting. They discover that after adopting inflation targeting, the economic performance of these countries improves. But, non-targeting countries also experience improvements around the same time. Thus, they argue that better economic performance reflects factors other than the monetary regime and conclude that inflation targeting does not produce a major effect. In other words, inflation targeting is irrelevant.

However, there are other studies that show a somewhat different result. [26] Provide a comparative analysis. They match three inflation-targeting countries (New Zealand, Canada, and the United Kingdom) with three nearby non-inflation-targeting countries (Australia, the United States, and Germany), finding little empirical evidence that an inflation-targeting regime performs better than a non-inflation-targeting regime. In addition, [27] states that "there is no evidence that inflation targeting has been detrimental to growth productivity, employment, or other measures of economic performance", a view supported by [28] in his comparison of 5 industrial countries that have been targeting inflation for at least 10 years and 6 non-inflation targeting industrial countries.

Finally, [29] use matching methods to evaluate the treatment effects of adopting inflation targeting on seven industrial countries with fifteen non-inflation targeting industrial countries as the non-treatment group. They show no significant effects on inflation and its variability, arguing the window-dressing view of inflation targeting. [30] uses the same method and sample data as [29], finding that inflation targeting does not significantly affect output growth or its variability. [31], however, show that inflation targeting OECD countries suffer smaller output losses in terms of sacrifice ratio during the disinflationary period than non-targeting counterparts. [32], employing intervention analysis, find lower inflation rates, wellanchored and accurate inflation expectations for both targeting and non-targeting countries.

In summary, we can say that the empirical studies reviewed fail to produce convincing evidence that IT improves inflation rate and economic stability. In addition, as [23] argue, the environment of the 1990s was in general terms a stable economic environment, "a period friendly to price stability" and inflation was on a downward trend in many countries, especially developed countries.

\subsection{Evidence in Developing Countries}

Recently, more than a dozen developing countries have officially adopted inflation targeting. Thus, a complete evaluation of the effectiveness of inflation targeting requires further evidence from developing countries. But, in 
general, most developing countries-whether they targeted inflation or not-performed much better in terms of growth and inflation since 2000 than during the 1990s. The evidence also shows that those that adopted inflation targeting tended to see bigger improvements than others, both in terms of inflation and growth performance ${ }^{12}$.

Reference [29] evaluates the effect of inflation targeting on inflation and inflation variability in thirteen developing countries that have adopted this policy by the end of 2004 , using a variety of propensity score matching methods. They found that inflation targeting has quantitatively large and statistically significant effects on lowering both inflation and inflation variability in these countries. On average, the adoption of inflation targeting has led to a reduction in the level of inflation by nearly 3 percent ${ }^{13}$. Following the methodology, [35] focus specifically on developing economies, excluding industrial economies from among their inflation targets and their non-inflation targets. They found that the effects of inflation targeting were statistically and economically significant.

On the another hand, [36] used panel data to assess the effect of inflation target in developing countries, and found no evidence that the inflation targeting regime improves performance of inflation and output growth in developing countries. That is, inflation targeting regimes do not lower the costs of disinflation. Finally, a group of scholars from Cambridge University conducted a painstaking research in the effect of inflation target, they concluded in these words: "We have attempted in this study to gauge empirical evidence for both developed and emerging countries that adopted the new monetary policy strategy that has come to be known as inflation targeting (IT). It may very well be the case that IT countries, developed and emerging, have been successful in taming and controlling inflation. But then there is also evidence that clearly suggests that non-IT central banks have also been successful in achieving and maintaining consistently low inflation rates".

The previous empirical findings produce mixed evidence in economic performance for developing and developed countries, but it seems developing countries gain more from inflation targeting policy than do developed countries.

The main conclusion that we can draw from these discussions is that it may very well be the case that inflation targeting countries, developed and emerging, have been successful in taming and controlling inflation. But then there is also evidence that clearly suggests that noninflation targeting central banks have also been success-

\footnotetext{
${ }^{12}$ [33], and [34] are among those who find more significant and positive effects of inflation targeting.

${ }^{13}$ These findings are consistent with the earlier conclusions of [24], and [23].

${ }^{14}$ De jure $\mathrm{CBI}$ would be equivalent to $\mathrm{CBI}$ as measured on the basis of legal documents whereas de facto $\mathrm{CBI}$ would be equivalent to $\mathrm{CBI}$ as factually implemented.
}

ful in achieving and maintaining consistently low inflation rates. Our overall conclusion, then, is that the available evidence we have managed to gauge clearly suggests that a central bank does not need to pursue an inflation targeting strategy to achieve and maintain low inflation, particularly during the mature phase of stationary targeting. The main question that arises is, is inflation target worthwhile for Egypt's Economy? To answer this question, we will try to assess, theoretically and empirically, if Egypt meets the preconditions for adopting an inflation target with some general comments on inflation targeting itself as a monetary policy.

\section{Is Egypt Ready for Adopting Inflation Targeting}

In this section, we try to analyze the prerequisites and applicability of inflation targeting in Egypt to evaluate its feasibility. The main focus will be on the assessment of whether the preconditions of inflation targeting are satisfied in Egypt. In order to do that, we explore three basic elements that are the precondition for adopting the inflation target: 1) Independence status of the Central bank of Egypt (CBE); and 2) inflation forecasting capability in Egypt; and 3) existence of relationship between the monetary policy instruments and inflation.

\subsection{Independence Status of the Central Bank of Egypt (CBE)}

Related to the institutional conditions discussed in the precondition requirements for adopting inflation targeting, the independence of the central bank seems to be the first feature that should be implemented. This ambiguity arises from the fact that there are several kinds of independence: political and economic, de jure and defacto, ${ }^{14}$ constitutional and statutory, independence within and independence from the government, strategic (to formulate policy) and tactical (day-to-day operations), instrument independence but not goal independence [37], and independence of the executive, judiciary, and legislative [38]. In this manner, we try to asses whether Egypt has satisfied the first preconditions for an IT regime in such a way that it makes the adoption of an IT regime in Egypt feasible to anchor individuals' expectations around the potential inflation targets. In order to do that, we explore two basic elements that are related to the institution conditions: 1) Independence status of the $\mathrm{CBE}$ from the government; and 2) absence of fiscal dominance including no obligation for the $\mathrm{CB}$ to finance budget deficits.

\subsubsection{Independence Status of the CBE from the Government}

In Egypt, the central bank governor is appointed by de- 
cree from the president of Egypt, for a renewable term of four years. The governor has two deputies appointed by decree and chosen on the proposal of the governor, for a renewable term of four years. The remaining nine members of the board of the CBE are also appointed by the president for a renewable four year ${ }^{15}$. While all board members (Governor, deputies and nine experienced persons) are nominated by a decree from the President of the Republic, the remuneration and attendance allowances of the nine specialized members are determined by a decree of the Prime Minister, upon a proposal from the Governor $^{16}$. The board is the authority responsible for realizing the objectives of the $\mathrm{CBE}$, by formulating and implementing monetary, credit, and banking policies. The board also determines the instruments required to achieve the objectives; particularly, the instruments of monetary policy to be followed, the structure of credit and discount rates, the regulatory and supervisory standards to guarantee the soundness of the financial position of banks, and the regulation of auctions and tenders.

Even though the explicit mention of monetary stability grants the CBE a degree of independence in implementing monetary policy vis-à-vis the government; law No. 93 of 2005, grants the CBE a higher degree of instrument independence, as it is free to set its discount rate and upper and lower limits for bank borrowing and lending rates and, in the absence of such limits, to make rules and directives to influence interest rate setting and credit expansion. However, the existence of government representatives as voting members on the Monetary policy committee and the fact that the governor are appointed by the decree of the president for a short term of four years, reflecting that the CBE still be seen as not fully independent according to law (de jure).

\subsubsection{Absence of Fiscal Dominance Including no Obligation for the CBE to Finance Budget Deficits}

As we mention before, to achieve effective inflation targeting, the central bank must not only have full legal autonomy but should be seen and act as one that has it and consequently be free from fiscal and political pressures that have the capacity to trigger objective that are in con-

\footnotetext{
${ }^{15}$ One can only criticize the subordination of the board members' remuneration to the head of the government because, in such circumstances, the autonomy of the members' decisions becomes questionable.

${ }^{16}$ The CBE has a board of directors under the chairmanship of the governor, with fourteen members (two deputy governors, the chairman of the Capital Market Authority, three members representing the ministries of finance, planning and foreign trade, and eight experts in monetary, financial, banking, legal, and economic affairs.

${ }^{17}$ According to [5], the contribution of the banking system to budget deficit was, on average, $45 \%$ of the overall budget deficit for the period of 2003-2006, while the involvement of the CBE in financing the budget deficit was, on average, $58 \%$ of the banking system contribution during the same period of 2003-2007, excluding the year 2006.
}

flict with the inflation targeting goal. As it is with the redenomination so it is with large fiscal deficits. This has continued to undermine the autonomy of the central bank with respect to monetary management. No matter how fiscal deficits are financed, they always have deleterious inflationary consequences. But this is worse when it is financed by ways and means usually in response to the pressure from the government. Egypt's fiscal disposition is largely characterized by a tradition of deficit budgeting financed mainly by means particularly during the last five years. Egypt's budget deficit has been high and the level of public debt has been around 65 percent of GDP. Table 1 exhibits some macroeconomic indicators in Egypt.

As we can see from Table 1, both the inflation rate and the output growth rate in Egypt have increased. A high output growth rate, in addition to the revenue coming from the privatization process, have both contributed to a lower budget deficit in FY 2006 and 2007. Impressively, however, the inflation rate witnessed a rise in 2007 to 2009 when it turned out to be in a double digit during this period and this is a not good outcome for IT.

A fiscal profile of the government shows that the high ratio of both the budget deficit and the public debt for the period of 2003-2009 were in conjunction with the high contribution of both the banking system and the CBE to financing the budget deficit ${ }^{17}$. Indeed, the structural budget deficit has been much higher than the transitory deficit, and fiscal discipline remains a problem. In Egypt, the rate of fiscal deficit has increased after 2005 and has been around 7\% during the 2006-2008 period. Unless this trend is radically changed, which is socially and politically a real challenge, sooner or later, this fiscal gap will generate excessive pressures on monetary policy. The current fiscal deficit is also the outcome of the pressures on fiscal revenues due to trade liberalization, and most of all to the high degree of tax evasion, in addition to inefficiency of the public expenditure.

On another hand, the public debt is also growing and putting an extra burden on the budget through debt interest payment. On average, the level of public debt in Egypt exceeds $60 \%$. Such a situation is emerging as a serious concern. Reducing this public debt ratio and in particular that of foreign currency dominated debt is therefore

Table 1. Selected Macroeconomic Indicators in Egypt 2003 -2009 .

\begin{tabular}{lcccccccc}
\hline & 2003 & 2004 & 2005 & 2006 & 2007 & 2008 & 2009 \\
\hline Real GDP Growth & 3.2 & 4.1 & 4.5 & 6.8 & 7.1 & 7.2 & 5.5 \\
CPI inflation(average) & 3.7 & 8.1 & 8.8 & 4.2 & 11.0 & 11.7 & 17.1 \\
Current account (\% GDP) & 2.4 & 4.3 & 3.2 & 0.8 & 1.4 & 0.5 & -1.8 \\
Budget deficit (\% GDP) & -9.5 & -9.6 & -8.2 & -7.3 & -6.8 & -6.9 & -5.8 \\
Public debt( \% of GDP) & 60.4 & 60.3 & 79.8 & 71.4 & 62.3 & 58.5 & 55.1 \\
\hline
\end{tabular}

Source: IMF and central bank of Egypt 
necessary to reduce the vulnerabilities in a context of a more exchange rate flexibility. For the time being, in Egypt, despite the progress achieved in the ratio of public debt in 2007-2009 compared to the previous periods, the government still relies on seigniorage revenues in order to close the transitory gap between its revenue and its expenditure flows. It is true that the reliance on seigniorage revenues is often higher in developing countries due to low and unstable incomes and poor tax collection procedures but this is not consistent with inflation targeting, and is likely to hamper the central bank's independence.

The conclusion one can draw from the previous facts is that the legal instrument independence granted to the CBE is sketchy and does not go beyond the de jure independence $^{18}$. Consequently, the existence of government representatives as voting members on the MPC and the coercion of the CBE to extend finance to the government are two elements sufficient to undermine any meaning of the de facto independence of the CBE.

\subsection{Inflation Forecasting Capability in Egypt}

As mentioned above, the inflation forecast is central to any inflation-targeting regime and requires a well-developed technical infrastructure, including quality data, construction of an appropriate price index, and forecasting and modeling capabilities. A forward-looking inflation targeting framework is, in fact, "inflation forecast targeting" [40]. Indeed, inflation targeting is not applied mechanically and does not focus only on current inflation but on containing inflation as a medium-term goal. Central banks pay attention to indicators that can predict future inflation [41].

To what extent is this technical infrastructure currently available in Egypt? Regarding the quality of data, unreliability of data is one of the major problems facing econometric modeling and estimation in Egypt which incidentally is central to price-inflation forecasting for inflation targeting. Even with so many reforms and improvement of the data collection in Egypt ${ }^{19}$, timely and reliable data availability remains an issue ${ }^{20}$. The absence of this desideratum means that we cannot meet the demands for full, timely, and accurate information on key variables such as GDP, financial and trade data etc. over required time periods. Since forecasting is at the heart of

\footnotetext{
${ }^{18}$ One of the tough critiques of the CCMP came from the Morgan Stanley report about the government, specifically the prime minister, overriding both the CCMP and the MPC of the CBE [39].

${ }^{19}$ In 2005, Egypt subscribed to the IMF's Special Data Dissemination System (SDDS), which requires prompt posting of various macroeconomic datasets, compiled in line with best International practice and comparable across countries.

${ }^{20}$ [42] using the Data Quality Assessment Framework (DQAF) to assess the quality of data in Egypt. the most defects in the Egyptian data were found in the accuracy and reliability.
}

inflation targeting, such forecasts may not be as robust as should be expected by its advocates since data is necessary to implement them. Although the CBE generates its own data, in some cases, particularly in the past, there are significant divergences among the data series being published on the same subject by other organizations with data-generating responsibility. These could have a consequence of fundamental disparities in data generating and reporting procedures.

Moreover, the use of the consumer price index (CPI) in Egypt for evaluating the inflation behaviour may serve a useful tool, but it will be risky if the CBE is planning to use it for the purpose of inflation targeting. As in all developing countries, choosing such an index is problematic. The first reason is that foodstuffs, which make up a large part of the basket, have highly variable prices because of their sensitivity to weather conditions. This high variability translates into more volatile CPI inflation. Second, goods and services with subsidized prices have a substantial share of the basket. Large movements in regulated prices, which have a direct impact on the overall price level, may lead to poor control of inflation and damage the central bank's credibility. In the Egyptian case, food \& non alcoholic beverages accounted for more than $50 \%$ of the old CPI basket, and still account for almost $40 \%$ of the current one. Within this category, bread, cooking oil and sugar benefit from consumption subsidies. Also subsidized are petroleum products (rent, power and fuel represent around $10 \%$ of the basket) pharmaceuticals (medical care represents 4\%), water, electricity \& gas (around 12\%), (CAPMAS, 2005). Given this information, one can conclude that having a target limited to the CPI in Egypt is a serious problem, because it will underpin any meaning of expectations about future inflation: a key determinant of actual inflation. The effectiveness of monetary policy as a nominal anchor depends on what is targeted and how. One of the fundamental problems arising from this framework is therefore the absence of a valid price index.

\subsection{Existence of Relationship between the Monetary Policy Instruments and Inflation}

In this section, we examine one of the main preconditions for a successful adoption of inflation targeting framework as expounded in many empirical studies and gives a solid understanding of the relationship between monetary policy instruments and macroeconomic outcomes via the monetary transmission mechanism. In order to quantify the importance of monetary policy variables in determining changes in the consumer price index (CPI) in Egypt, this paper adopts the Granger causality tests in both bivariate and multivariate using the baseline VAR model form which is employed by [43] and, more recently, by [44]. The baseline VAR model representation 
is given by:

$$
Y_{t}=A(L) Y_{t-1}+\beta(L) Z+\varepsilon_{t}
$$

where $Y_{t}$ is a k vector of endogenous variables, $Z_{t}$ is a $\mathrm{d}$ vector of exogenous variables, and $A$ and $\beta$ are matrices of coefficients, and $\varepsilon_{t}$ is a vector of structural shocks with the variance covariance matrix $\mathrm{E}\left(\varepsilon \varepsilon^{\prime}\right)=\rho$.

In the baseline model, the vector of endogenous variables consists of the gross domestic product (GDP), consumer price index $(C P I)$, Broad money supply $(M 2)$, Government fiscal spending $(F S)$, interest rate $(R)$ and exchange rate $(E X)^{21}$ :

$$
Z_{t}=(G D P, C P I, M 2, F S, R, E X),
$$

In order to apply the Granger casualty test in a VAR framework, the general mathematical representation of the test can be written as:

$$
\begin{aligned}
& y_{t}=\alpha_{t}+\sum_{j=1}^{m} \beta_{1 j} y_{t-j}+\sum_{j=1}^{m} \delta_{1 j} z_{t-j}+\varepsilon_{1 t} \\
& z_{t}=\alpha_{2}+\sum_{j=1}^{m} \beta_{2 j} z_{t-j}+\sum_{j=1}^{m} \delta_{2 j} z_{t-j}+\varepsilon_{2 t}
\end{aligned}
$$

where $\alpha_{i}$ are the constant terms, $m$ is the lag order, and $\alpha_{i t}$ are error terms and assumed to be serially uncorrelated with zero mean and finite covariance matrix. In order to test causality from $z$ to $y$, the null hypothesis $\left(H_{01}\right)$ is expressed as $\alpha_{1 j}=0(j=1,2, \ldots, m)$ and the alternative is at least one of $\alpha_{1 j}=(j=1,2, \ldots, m)$, is significantly different from zero. Similarly, $\left(H_{02}\right)$ of testing the causality from $y$ to $z$ is $\alpha_{2 j}=0$ ( $j=$ $1,2, \ldots, m)$ against at least one of $\alpha_{02}$ is not zero.

The paper used annual data from 1998Q1 to 2009Q4 gathered from the International Monetary Fund's International Financial Statistics, and Central Bank of Egypt. Table 2 presents the results of the bivariate and multivariate block Granger causality tests for CPI and GDP in Egypt.

As we can see in Table 2, the results suggest the causal link between the policy variables on consumer price index and gross domestic product. The joint probabilities for the multivariate tests suggest the rejection of the null hypothesis. The bivariate tests for Cosumer price index (CPI) suggest that all the variables except interest rate and money supply cause significant variations in CPI. This means that the level of output, exchange rate and fiscal spending cause variations in the level of prices or

\footnotetext{
${ }^{21}$ All variables are in $\log$ s for all variables except interest rate where we have used the level.

${ }^{22}$ This is expected since in a small open economy like Egypt, prices of traded goods return rapidly to world levels following an exchange rate appreciation.
}

the $\mathrm{CPI}^{22}$. The findings support that the fact that fiscal policy is also important for achieving price stability and economic growth. In addition, the bivariate tests show that money supply has a significant Granger-effect on output but not on prices. The empirical results suggest that Egypt's exchange rate is quite significant with respect to GDP as with CPI. This is not surprising given the recent float of the Egyptian currency, and the subsequent positive effects on exports and the rate of growth of GDP. The results also show consumer price index, money supply, and government fiscal spending significantly drive GDP.

The previous results show that the interest rate and money supply as a monetary target regime are not sufficient in the Egyptian economy to send the right message to individuals to adjust their expectation about inflation. Meaning that, the mechanism of the inflation targeting model, as presented in Section 2, undermines the inflation target.

Another important point of concern is about the indirect effect between the money supply and inflation. It seems that the impact of money supply adjustments on inflation is not a one-time strike on inflation. Therefore when the monetary policy rate is adjusted in order to influence other rates, which invariably affects the spending decisions of economic actors, it neither affects the economy nor inflation in a manner that is readily predictable.

The transmission mechanism of monetary policy has long and variable lags because the economy takes time to adjust to changes in monetary conditions. Inflation targeting however does not seem to operate within this frame of reasoning which suggests that the actual inflation can be adjusted to hit the target inflation within a short period if a deviation is observed. This belief is just deceptive. What happens is merely the suppression of the truth about the prevailing conditions of inflation. According to the previous points, if we recognize the causes and uproot the inflation in Egyptian economy, then that problem is almost solved. It is expected that the focus of

Table 2. Granger Causality Tests: Baseline VAR, 1998$20091 /$.

\begin{tabular}{cccccc}
\hline $\begin{array}{c}\text { Effect on } \\
\text { CPI }\end{array}$ & \multicolumn{6}{c}{ Chi-square probability } & $\begin{array}{c}\text { Effect on } \\
\text { GDP }\end{array}$ & Chi-square probability \\
\hline GDP & 15.14 & $0.001^{*}$ & CPI & 10.57 & $0.004^{*}$ \\
M2 & 3.10 & 0.681 & M2 & 6.61 & $0.092^{* *}$ \\
FS & 8.45 & $0.057^{* *}$ & FS & 8.59 & $0.064^{* *}$ \\
R & 5.66 & 0.249 & R & 4.89 & 0.138 \\
EX & 12.84 & $0.003^{*}$ & EX & 11.59 & $0.005^{*}$ \\
Jointly & 33.67 & $0.000^{*}$ & Jointly & 41.27 & $0.000^{*}$ \\
\hline
\end{tabular}

Source: Authors' calculations.

1/ The block Granger causality test for exclusion of a variable is based on a Wald test and follows a $\chi^{2}$ distribution; * and ** denote rejection of the exclusion at the 1 and 5 percent level. 
monetary policy should be on the management of the primary source of inflation which in itself is unrestricted fiscal, monetary and credit expansion by the government using the instrumentality of the bank. What this means is that the central bank should first of all manage the money creation process from both the financing of government's fiscal deficits as well as the growing penchant for loosening banks credit creation capacity. Once this is resolved within the context of the rule of law, the efficient justice system for the protection of private property rights, and eradication (or serious reduction) of public sector corruption, inflation will naturally drop to very low minimums and the economy will grow very strongly.

\section{Concluding Remarks}

This paper gave a systematic review of the Inflation targeting regime. The fundamental question was whether scientific evidence - theoretical and empirical — exists to support the inflation targeting regime. A closer look at the Egypt case was presented by reviewing recent evidence to assess whether it is ready to switch to the inflation target or not.

The paper concludes that: 1) There is insufficient evidence to show that an inflation targeting regime is effective as a monetary policy framework for the achievement of macroeconomic stability or price stability, and 2) the Central bank of Egypt and by extension, Egypt, is not yet ready for the implementation of the inflation targeting framework. This is because the stringent conditions required-based on the experiences of countries who have adopted it-are not yet met, and 3) more research should be conducted on main sources of inflation in the Egyptian economy in order to give a more informed picture to policy makers so they can to adopt better policies according evidence.

\section{References}

[1] F. Kydland and E. Prescott, "Rules Rather Than Discretion: The Inconsistency of Optimal Plans," Journal of Political Economy, Vol. 85, No. 3, 1977, pp. 473-492.

[2] S. Roger and M. Stone, "On Target? The International Experience with Achieving Inflation Targets," IMF Working Paper WP/05/163, Washington D.C., 2005.

[3] L. Ball and N. Sheridan, "Does Inflation Targeting Matter?" In: B.S. Bernanke and M. Woodford, Eds., the Inflation-Targeting Debate, University of Chicago Press, Chicago, 2005, pp. 249-276.

[4] R. Al-mashat, "Monetary Policy in Egypt: A Retrospective and Preparedness of Inflation Targeting," ECES Working Paper, No. 134, 2008.

[5] I. L. Awad, "Is Egypt Ready to Apply Inflation Targeting Regime?" Review of Economic and Business Studies, No. 2, 2008 .
[6] G. Debelle and C. H. Lim, "Preliminary Considerations of an Inflation Targeting Framework for the Philippines," IMF Working Paper WP/98/39, Washington D.C., March 1998.

[7] P. R. Masson, M. A. Savastano and S. Sharma, "The Scope for Inflation Targeting in Developing Countries," IMF Working Paper WP/97/130, Washington D.C., October 1997.

[8] E. Tutar, "Inflation Targeting in Developing Countries and Its Applicability to the Turkish Economy," An Unpublished M. A. Economics Thesis Submitted to the Faculty of the Virginia Polytechnic Institute and State University Blacksburg, Virginia, 2002.

[9] E. Truman, "Inflation Targeting in the World Economy," Institute for International Economics, Washington D.C., 2003.

[10] G. Bakradze and A. Billmeier, "Inflation Targeting in Georgia: Are We There Yet?" IMF Working Paper WP /07/193, International Monetary Fund, Washington D.C., 2007.

[11] L. Leiderman and L.E.O. Svensson, "Inflation Targets," Centre of Economic Policy Research, London, 1995.

[12] H. Schmidt and F. Mishkin, "Monetary Policy under Inflation Targeting," Central Bank of Chile, Santiago, 2005.

[13] B. S. Bernanke and F. S. Mishkin, "Inflation Targeting: A New Framework for Monetary Policy?" Journal of Economic Perspectives, Vol. 11, No. 2, pp. 97-116.

[14] T. G. Petursson, "Exchange Rate or Inflation Targeting in Monetary Policy?" Center Bank of Iceland Monthly Bulletin, Vol. 2000, No. 1, 2000, pp. 36-45.

[15] U. Hazirolan, "Inflation Targeting: Japanese Case and Prospects for Turkey," Undersecreteriat of the Treasury, Ankara, 1999.

[16] F. S. Mishkin, "Issues in Inflation Targeting, Price Stability and the Long-Run Target for Monetary Policy," Ottawa, Bank of Canada, 2001.

[17] L. Meyer, "Does Money Matter?" Federal Reserve Bank, St. Louis, 2001

[18] F. S. Mishkin and K. Schmidt-Hebbel, "A decade of inflation targeting in the world: What do we know and what do we need to know?" In: F. S. Mishkin Ed., Monetary Policy Strategy, The MIT Press, Cambridge, Massachusetts, 2007, pp. 117-219.

[19] V. Corbo, M.O. Landerrretche and H. K. Schmidt, "Does Inflation Targeting Make a Difference?" In: N. Loayza and R. Saito Eds., Inflation Targeting: Design, Performance, Challenges, Central Bank of Chile, Santiago, 2002, pp. 221-270.

[20] G. Jonsson, "The Relative Merits and Implications of Inflation Targeting for South Africa," IMF Working Paper WP/99/116, Washington D.C., August 1999.

[21] U. Hazirolan, "Inflation Targeting: Japanese Case and Prospects for Turkey," Undersecreteriat of the Treasury, Ankara, 1999.

[22] F. Mishkin and H. K. Schmidt, "One Decade of Inflation Targeting in the World: What do We Know and What do 
We Need to Know?" In: N. Loayza and R. Soto Eds., Inflation Targeting: Design, Performance, Challenges, Central Bank of Chile, Santiago, 2002, pp. 171-219.

[23] J. M. Neumann and J. von Hagen, "Does Inflation Targeting Matter?" Federal Reserve Bank of St. Louis Review, Vol. 84, No. 4, 2002, pp. 127-148.

[24] V. Corbo, M.O. Landerrretche and K. Schmidt-Hebbel, "Does Inflation Targeting Make A Difference?" In: N. Loayza and R. Saito, Eds., Inflation Targeting: Design, Performance, Challenges, Central Bank of Chile, Santiago, .

[25] L. Ball and N. Sheridan, "Does Inflation Targeting Matter?" In: B. S. Bernanke and M. Woodford Eds., The Inflation-Targeting Debate, University of Chicago Press, 2005, pp. 249-276.

[26] M. J. Dueker and A. M. Fischer, "Do Inflation Targeters Outperform Non-Targeters?" Federal Reserve Bank of St. Louis Review, Vol. 88, No. 5, 2006, pp. 431-450.

[27] L. Svensson, "Inflation Targeting," In: L. Blum and S. Durlauf, Eds., The New Palgrave Dictionary of Economics, 2nd Edition, 2007.

[28] M. Dotsey, "A Review of Inflation Targeting in Developed Countries," Federal Reserve Bank of Philadelphia Business Review, No. Q3, 2006, pp. 10-20.

[29] S. Lin and H. Ye, "Does Inflation Targeting Really Make a Difference? Evaluating the Treatment Effect of Inflation Targeting in Seven Industrial Countries," Journal of Monetary Economics, Vol. 54, No. 8, 2007, pp. 25212533.

[30] C. E. Walsh, "Inflation Targeting: What Have We Learned?" International Finance, Vol. 12, No. 2, 2009, pp. 195-233.

[31] C. Gonçalves and A. Carvalho, "Inflation Targeting Matters: Evidence from OECD Economics' Sacrifice Ratios," Journal of Money, Credit and Banking, Vol. 41, No. 1, 2009, pp. 233-243.

[32] A. Angeriz and P. Arestis, "Assessing Inflation Targeting through Intervention Analysis," Oxford Economic Papers, Vol. 60, No. 2, 2008, pp. 293-317.

[33] Batini, Nicoletta, and D. Laxton, "Under What Conditions Can Inflation Targeting Be Adopted? The Experi- ence of Emerging Markets," Working Papers Central Bank of Chile, No. 406, Central Bank of Chile, 2005.

[34] Vega, Marco, and Diego Winkelried, "Inflation Targeting and Inflation Behavior: A Successful Story? International Journal of Central Banking, Vol. 1, No. 3, 2005, pp. 153175.

[35] C. Goncalves and J. M. Salles, "Inflation Targeting in Emerging Economies: What do the Data Say?" Journal of Development Economics, Vol. 85, No. 1-2, 2008, pp. 312-318.

[36] R. D. Brito and B. Bystedt, "Inflation Targeting in Emerging Economies: Panel Evidence," Journal of Development Economics, Vol. 91, No. 2, 2009, pp. 198-210.

[37] G. Debelle and S. Fischer, "How Independent Should a Central Bank be?" In: J. C. Fuhrer Ed., Goals, Guidelines and Constraints Facing Monetary Policymakers, Federal Reserve Bank, Boston, Conference Series No. 38, 1994, pp. 195-221.

[38] A. Chandavarkar, "Central Banking in Developing Countries," Macmillan Press LTD, New York, 1996.

[39] S. Cevik, "When a Prime Minister Makes Monetary Policy," Morgan Stanley Report about Egypt, 2007. www. morganstanley.com/views/gef/archive/2007/20070328-W ed.html

[40] L. Svensson, "Inflation Forecast Targeting: Implementing and Monitoring Inflation Targets," European Economic Review, Vol. 41, No. 6, 1997, pp. 1111-1146.

[41] B. S. Bernanke and F. S. Mishkin, "Inflation Targeting: A New Framework for Monetary Policy?” Journal of Economic Perspectives, Vol. 11, No. 2, 1997, pp. 97-116.

[42] IMF, "Arab Republic of Egypt: Report on the Observance of Standards and Codes-Data Module," IMF Country Report, No. 05/238, Washington DC, 2005.

[43] J. Gottschalk and D. Moore, "Implementing Inflation Targeting Regimes: The Case of Poland," Journal of Comparative Economics, Vol. 29, No. 1, March 2001, pp. 24-39.

[44] G. Bakradze and A. Billmeier, "Inflation Targeting in Georgia: Are We There Yet?" IMF Working Paper WP /07/193, International Monetary Fund, Washington D.C., 2007. 